\title{
Ketika Demokrasi Membutuhkan Inklusi
}

\author{
Sylvester Kanisius Laku. \\ sylvesterkanisius@gmail.com
}

\begin{abstract}
Abstrak
Democracy is a political tool that aims to reach agreement and produce fair decisions for everyone. However, it seems that not all democratic processes and decision-making involve individuals or groups who are socially in a weak, powerless, and marginalized position. These groups, such as women, the elderly, minority groups, and the poor, find themselves in a disadvantageous situation, while political decisions made through a democratic process also impact and affect them directly. Based on this thought, Iris Marion Young, a modern feminist political thinker, seeks to dismantle the various democratic symptoms that obstruct the achievement of justice for all. One of the main problems Young identified is the attempt by those in power to ignore or override the role of communities that are not in power, thereby preventing them from taking full part in democratic processes and decision-making. Therefore, Young proposes the need to intrude on inclusion in the democratic process, through communication models which she calls communicative democracy.
\end{abstract}

Keywords: Demokrasi, keadilan, imanensi, transendensi, inklusi, eksklusi, dominasi, penindasan, komunikasi, sapaan, retorika, narasi.

Sylvester Kanisius Laku, SS., M.Pd. adalah Dosen Fakultas Filsafat Universitas Katolik Parahyangan, Bandung. Kandidat Doktor Filsafat di Sekolah Tinggi Filsafat Driyarkara, Jakarta.

\section{Pendahuluan}

Demokrasi telah bergumul dengan problem partisipasi sejak zaman polis Yunani hingga saat ini. Siapa yang seharusnya menjadi demos dan bagaimana demos itu menjalankan fungsinya agar kepentingan warga negara yang lain terwakili adalah problem khas demokrasi yang masih ditemui dan diperkarakan hingga dewasa ini. ${ }^{1}$ Sekalipun demokrasi diyakini sebagai model terbaik karena menyertakan warga negara dalam proses pengambilan keputusan dan dianggap dapat mengatasi 
ketidakadilan, itu tidak berarti, baik teori maupun praksisnya, sudah jelas dengan sendirinya, sehingga bebas dari cacat dan kritik. Salah seorang pemikir politik yang berupaya membongkar sisi lemah demokrasi adalah Iris Marion Young. Kerisauan utamanya adalah bagaimana mestinya demokrasi diwujudkan agar baik proses maupun hasil keputusannya dapat sungguh-sungguh memenuhi keadilan yang menjangkau kelompok-kelompok yang secara sosial-politik terkucilkan, jika tidak mau disebut tertindas. Tesis Young bahwa melalui inklusi demokrasi, terutama melalui apa yang dia sebut demokrasi komunikatif, ketidakadilan dan ketidaksetaraan sosial-politik dapat teratasi.

Makalah ini tidak bermaksud memperkarakan dan memperdebatkan tesis Young di atas, tetapi mencoba menalar lebih jauh dan dalam, problem fundamental tersebut sambil menawarkan kemungkinan pemahaman baru yang lebih luas dan solutif. Pertanyaan yang coba dikemukakan dalam makalah ini adalah bagaimana inklusi dimungkinkan sementara karakter khas politik demokrasi adalah partisan dan itu berarti menciptakan eksklusifitas?

\section{Belenggu Imanensi}

Refleksi politik Young berakar pada pengalamannya sebagai seorang feminis. Karena itu, makalah ini akan saya mulai dengan menelusuri dan memaparkan secara ringkas pemikiran feminismenya. Pemikiran ini sangat penting karena menjadi akar dari refleksi filosofisnya yang berupaya membongkar praktik-praktik sosial-politik yang menyumbat keran demokrasi sehingga mengakibatkan ketidakadilan.

Young menyaksikan bahwa dalam kultur masyarakat modern saat ini, masih hidup dan berkembang pemahaman dan kepercayaan bahwa struktur sosial dan kultur adalah institusi obyektif penentu identitas eksistensial manusia. Identitas tersebut dalam bentuk pembatasan-pembatasan dalam aspek-aspek kehidupan yang biasa dihayati dan dijalani. ${ }^{2}$ Pembatasan-pembatasan tersebut dianggap sebagai pilihan rasional yang perlu untuk melindungi mereka yang lemah (perempuan) dari berbagai hal yang kasar, keras, bahkan mungkin brutal. Sebagaimana diungkapkannya, 
"Berbagai bentuk pembatasan mendefinisikan pilihan yang tersedia untuk individu atau mendefinisikan kualitas untuk mengejar beberapa pilihan penting yang dibutuhkan sebagai aset dasar... dan preferensi tertentu menciptakan batasan yang mendefinisikan apa yang kita sebut kelompok sosial berdasarkan jenis kelamin, kelas, ras, usia, dan sebagainya." ${ }^{3}$ Identitas yang ditemukan pada beberapa kelompok sosial berasal dari pembatasan semacam itu yang disisipkan ke dalam kesadaran atau diindoktrinasi secara struktural.

Menurut Young pada banyak budaya dan masyarakat, kelompok masyarakat yang tidak berdaya (secara spesifik perempuan) masih dianggap sebagai 'yang lain', yang tidak sama bahkan tidak memiliki korelasi essensial dengan kelompok dominan (laki-laki). ${ }^{4}$ Kelompok rentan, seperti yang dihadapi kaum perempuan, dipandang semata-mata sebagai obyek yang selalu terikat dan melekat dengan imanensinya, dengan interioritas yang dibentuk atau dikonseptualisasikan oleh kelompok dominan (patriark). ${ }^{5}$ Ciri dan karakter seperti tidak berdaya, lemah, lembut, halus, dan lain sebagainya, selalu dipersepsikan pada kelompok-kelompok lemah sebagai ciri pokok yang melekat pada identitas mereka dan persepsi semacam ini diwariskan secara struktural. Imanensi paradigmatik semacam ini, menurut Young, adalah sebuah kekeliruan ideologis karena merendahkan posisi mereka dan membuat mereka terasing dari dunia dan lingkungan di sekitarnya.

Identitas kelompok sosial sebagai produk pemikiran kelompok dominan selalu berada dalam situasi paradoks antara kebebasan untuk mewujudkan subyektifitas mereka dan mentransendensikan seluruh potensi yang dimiliki ke dunia aktual serentak tunduk pada keharusan sosio-kultural yang mengikat dan membelenggu. Young menilai bahwa tegangan antara imanensi dan transendensi semacam ini memasung potensi yang dimiliki untuk berkembang. ${ }^{6}$ Sebagaimana dikatakannya, "Dalam masyarakat semacam itu banyak perempuan memilih untuk tinggal di dalam imanensinya dan menjalaninya sebagai yang sungguh-sungguh real." ${ }^{, 7}$ Itulah bentuk trensendensi ambigu, yang menempatkan kelompok-kelompok seperti kaum perempuan pada situasi antara. ${ }^{8}$ 
Alih-alih mengarahkan seluruh kemampuan tubuh keluar dari dirinya dan secara bebas terbuka terhadap lingkungan di sekitarnya, individu cenderung menghindari transendentalisasi diri secara aktual dan sungguh-sungguh. Dalam arti individu memilih untuk berdiam dalam imanensinya. Dalam situasi seperti ini individu sering mengalami dirinya sebagai beban, dimana ada tuntutan menggunakan seluruh bagian dirinya untuk beraktivitas, sementara pada saat yang sama ada keharusan untuk menekan dan menyembunyikannya. Di sini imanensi membelenggu transendensi karena kecemasan dan keragu-raguan menggunakan kemampuannya keluar batas dirinya.

Berhadapan dengan situasi ini, Young menekankan pentingnya memahami diri sebagai tubuh yang hidup yang berbeda dari mesin atau obyek. Meminjam Husserl, Young menjelaskan bahwa 'tubuh yang hidup' adalah tubuh yang dijalani atau dihidupi, untuk membedakan dengan tubuh yang bersifat fisikal semata. ${ }^{9}$ Tubuh yang hidup adalah tubuh yang dirasakan dan dialami dengan seluruh inderawi yang dimiliki. Husserl menegaskan bahwa tubuh yang hidup adalah tubuh-dalamkehidupan. Totalitas tubuh pada akhirnya adalah kemampuan untuk bergerak dan mengaktualisasikan seluruh potensi yang dimiliki individu. Tubuh yang hidup secara spesifik hidup dalam konteks tertentu, menjalani relasi tertentu, mendengar bahasa tertentu, memiliki makanan dan tempat tinggal yang tersedia, atau tidak, sebagai akibat dari proses sosial budaya tertentu yang membuat persyaratan khusus pada dirinya untuk mengakses mereka. ${ }^{10}$ Karena itu, semua hubungan material konkret tubuh yang berada dengan lingkungan fisik dan sosialnya merupakan sebuah faktisitas. $^{11}$

Refleksi tentang belenggu imanensi yang menghambat aktualisasi dan realisasi potensi dan kemampuan diri secara total sebagai dampak tekanan sosial-struktural yang mensituasikan dan mengkondisikan sekelompok masyarakat inilah yang mengarahkan pemikiran Young tentang pentingnya perjuangan politik bagi kaum lemah, tidak berdaya, marginal secara sosial, struktural, dan politik. Ini dimaksudkan agar kelompok-kelompok yang selama ini tersisih dapat mencapai keadilan yang 
sungguh-sungguh sesuai dengan kekhasan dan partikularitas yang menandai masingmasing.

\section{Tendesi yang Menghambat Partisipasi}

Belenggu imanensi sebagaimana dijelaskan di atas merupakan dampak dari relasi struktural yang tidak adil yang dialami bukan saja oleh kaum perempuan, melainkan juga oleh banyak kelompok sosial lain yang mengalami perlakuan serupa. Young berpandangan bahwa paradigma struktural yang menempatkan kelompok-kelompok rentan seperti kaum perempuan, kaum miskin, kaum disabilitas, kaum lansia, kelompok minoritas, dan sebagainya, dalam konteks politik demokrasi, menghambat individu maupun kelompok untuk merealisasikan potensi-potensi yang dimiliki. Kelompok-kelompok ini selalu menjadi obyek politik, tetapi keterlibatan mereka terbatas atau dibatasi. Saya mencatat setidak-tidaknya terdapat empat kecenderungan praktik demokrasi yang menghambat partisipasi dan menciptakan ketidakadilan di antaranya eksklusi, dominasi dan penindasan (oppression), ketidaksetaraan struktural, dan politik persamaan.

Ekslusi - Young mengemukakan bahwa di dunia nyata beberapa orang atau kelompok memiliki kemampuan yang sangat besar untuk menggunakan proses demokrasi bagi kepentingan dan tujuan mereka sendiri sementara yang lainnya dikecualikan atau dimarginalisasi. ${ }^{12}$ Bahkan, "Diskusi kebijakan demokratis tidak terjadi di bawah kondisi bebas dari paksaan dan tekanan, dan bebas dari pengaruh yang mendistorsi kekuasaan yang tidak setara dan kontrol yang melampaui sumber daya."13 Situasi dan kondisi semacam ini merupakan kecenderungan yang sangat kuat yang terlihat ketika demokrasi dipraktikkan dalam berbagai bentuk dan wujudnya.

Kenyataan semacam inilah yang disebut sebagai eksklusi atau pengecualian. ${ }^{14}$ Praktik Eksklusi tak terelakkan setidak-tidaknya karena dua hal, pertama adanya kompetisi atau persaingan antara partai atau kandidat. ${ }^{15}$ Persaingan semacam ini adalah keniscayaan karena demokrasi sendiri adalah upaya untuk menawarkan pereferensi serta merebut pengaruh dan simpati yang dilakukan partai-partai politik dan para 
kandidat. ${ }^{16}$ Pandangan yang sama dikemukakan Judith Bara dan Albert Weale yang mengibaratkan persaingan dalam demokrasi seperti pasar ekonomi dalam kondisi tertentu di mana persaingan dapat menghadirkan hasil yang bermanfaat bagi konsumen ${ }^{17}$ atau kesan yang lebih kuat seperti diperlihatkan Kaare Strom yang menegaskan bahwa demokrasi hanya mungkin berlangsung dan berkembang dalam sistem kompetisi antar partai politik dan antara para kandidat. ${ }^{18}$

Alasan kedua adalah ketidaksetaraan ekonomi, sosial, maupun kultural yang menyebabkan ketidakseimbangan dan ketimpangan. Young mengemukakan, "Bahaya kemiskinan, atau eksploitasi dalam dunia, atau kekerasan dalam rumah tangga, atau prasangka rasial sering menghambat partisipasi politik beberapa warga negara yang secara formal memiliki hak yang sama, pada saat yang sama secara relatif mereka memberdayakan yang lainnya. ${ }^{19}$ Akibatnya terjadi pengecualian atau pengabaian terhadap suara dan pengaruh kelompok-kelompok sosial tertentu sambil memperbesar pengaruh kelompok yang lainnya.

Cara kerja politik demokrasi menurut Young dapat dibedakan ke dalam dua bentuk, yaitu eksklusi eksternal dan internal. Eksklusi eksternal adalah cara-cara dimana individu atau kelompok yang seharusnya terlibat, secara sengaja atau tidak sengaja, dikecualikan atau diabaikan dari forum diskusi atau pengambilan keputusan. ${ }^{20}$ Berbeda dengan eksklusi eksternal, yang dimaksudkan dengan eksklusi internal adalah cara dan mekanisme untuk mengecualikan dan meniadakan peran kelompok lain, bahkan ketika mereka memiliki akses ke dalam proses dan prosedur musyawarah dan pengambilan keputusan. Young mengemukakan, "Saya menyebut situasi semacam ini eksklusi internal, karena mereka menggunakan cara-cara untuk mengurangi kesempatan yang efektif bagi orang-orang untuk mempengaruhi pemikiran orang lain bahkan ketika mereka memiliki akses ke dalam forum atau prosedur pengambilan keputusan."21 Bahkan ketika mendapatkan akses ke dalam ruang diskusi atau musyawarah publik, warga yang dieksklusi terkadang menemukan bahwa mereka diabaikan atau direndahkan atau diremehkan, dan tidak mendapatkan penghargaan yang layak atas persepsi atau pengalaman mereka. Karena alasan itulah Young menyebut eksklusi sebagai salah satu sumber ketidakadilan, apalagi didukung 
sebuah egoitas; dorongan untuk kepentingan diri pribadi demi memaksimalkan tujuan diri sendiri, dan bukannya demi kebutuhan untuk mendengarkan atau menanggapi tuntutan-tuntutan pihak lain. ${ }^{22}$

Dominasi dan Oppresi - Praktik dominasi dan penindasan (oppression) dilakukan oleh sekelompok orang berkuasa terhadap yang tidak memiliki kekuasaan. Ini adalah dampak dari distribusi kekuasaan yang tidak seimbang, yang terpusat pada segelintir orang atau sekelompok orang. Young mendefinisikan penindasan (oppression) sebagai, "proses kelembagaan yang secara sistematis mencegah beberapa orang untuk belajar dan menggunakan keterampilan atau kemampuan yang layak dan berkembang dalam pengaturan yang diakui secara sosial, atau proses sosial yang dilembagakan yang menghambat kemampuan orang untuk berperan dan berkomunikasi dengan orang lain atau untuk mengekspresikan perasaan dan perspektif mereka tentang kehidupan sosial dalam konteks di mana orang lain dapat mendengarkan."23 Dari pengertian ini dapat dijelaskan bahwa dominasi adalah sebuah upaya terstruktur untuk menguasai orang lain dengan menggunakan kekuasaan atau kekuatan dengan tujuan menghambat kebebasan, tuntutan akan kesetaraan, dan keberpihakan.

Philip Pettit mengidentikkan penindasan dengan ketiadaan kebebasan karena ketidakmampuan seseorang untuk menentukan atau menguasai dirinya sendiri. ${ }^{24}$ Pettit menganalogikan dominasi dengan hubungan antara tuan dan budak. Hubungan seperti itu berarti, pada batas tertentu, pihak yang mendominasi dapat mencampuri secara sewenang-wenang pilihan-pilihan pihak yang didominasi. ${ }^{25}$ Sally Hasllanger menggunakan istilah dominasi dan penindasan untuk menggambarkan cara dimana sekelompok orang secara sistematis dan tidak adil mengalami perlakuan yang merugikan dalam sebuah struktur sosial partikular. ${ }^{26}$ Gagasan tentang penindasan menurutnya mensyaratkan adanya seorang atau beberapa agen yang menyalahgunakan kekuasaan mereka untuk membahayakan orang lain. ${ }^{27}$

Ian Saphiro setuju bahwa dominasi selalu terkait dengan kekuasaan. Menurutnya, "Dominasi memang sering diakibatkan oleh maldistribusi sumber daya, tetapi tidak semua ketidaksetaraan distributif melahirkan dominasi. ${ }^{28}$ Jelas juga dominasi 
melibatkan hubungan kekuasaan, tetapi tidak setiap pelaksanaan kekuasaan adalah dominasi. Memang, kekuasaan sering dibutuhkan untuk memerangi dominasi. Orang sering tahu dominasi ketika mereka melihat atau mengalaminya, tetapi sulit untuk mendefinisikannya sebagian karena ide kemiripan keluarga (family resemblance idea), seperti yang telah saya catat. ${ }^{29}$

Dalam praktik, penindasan menjelma dalam lima bentuk atau wajah, eksploitasi yang terjadi melalui upaya penggunaan atau pengisapan suatu kelompok sosial demi keuntungan kelompok lainnya. ${ }^{30}$ Marginalisasi dimana sekelompok orang secara terstruktur dan sistematis diisolasi atau disingkirkan dari kehidupan sosial dan tidak dapat berpartisipasi menentukan nasib mereka yang menyebabkan mereka sangat rentan kehilangan hak-hak mereka dan bahkan bisa mengarah kepada pembinasaan. ${ }^{31}$

Ketidakberdayaan (powerlessness) dalam pengertian mereka yang tidak memiliki otoritas atau kekuasaan, termasuk mereka yang memiliki kekuasaan dan tidak dapat menggunakannya atau dalam bahasa yang berbeda ketidakberdayaan tersebut disituasikan atau dikondisikan sedemikian sehingga orang yang tidak berdaya hanya dapat menerima dan mengikuti perintah tanpa pernah memiliki hak untuk menggunakan kekuatan mereka. ${ }^{32}$ Wajah penindasan berikut adalah imperialisme kultur sebagai akibat dari universalisasi pengalaman dan kultur dominan yang kemudian dikembangkan atau diperluas sebagai norma. ${ }^{33}$ Dan terakhir adalah kekerasan (violence) yang dilakukan kelompok tertentu terhadap kelompok lain dalam masyarakat dengan motif dan tujuan semata-mata untuk merusak, menghina, meneror, atau menghancurkan mereka. ${ }^{34}$

Ketidaksetaraan Struktural - Dalam pandangan Young, di dalam struktur terkandung sumber daya normatif, institusi, dan material yang berpotensi membentuk atau memproduksi aturan dan kondisi-kondisi yang memberdayakan atau membatasi orang-orang yang terlibat di dalamnya. Menurut Young, "Seseorang menderita ketidakadilan tidak mengacu pada sejarah hidupnya yang khusus, tetapi lebih pada posisinya yang rentan.... Posisi ini merupakan posisi sosial-struktural." 35 Pendapat ini menunjukkan bahwa seseorang atau sekelompok orang dapat saja mengalami 
ketidakadilan, bukan karena pilihan atau tindakan mereka, tetapi karena posisi dimana mereka berada.

Ketidaksetaraan kelompok sosial yang terstruktur berarti bahwa orang-orang yang dikategorikan dalam posisi tersubordinasi umumnya menghadapi hambatan yang lebih besar dalam mencapai keinginan dan kepentingan mereka, atau memiliki rentang peluang yang lebih sempit yang ditawarkan kepada mereka untuk mengembangkan kapasitas dan menjalankan otonomi atas kondisi yang menyertai mereka. ${ }^{36}$ Ketimpangan struktural seperti itu dianggap sebagai ketidakadilan berbasis kelompok, karena hal tersebut melanggar prinsip kesetaraan kesempatan yang substantif. Atau sebagaimana diutarakan Young, ketidakadilan dianggap bersifat struktural ketika ada perlakuan diskriminatif terhadap kelompok-kelompok sosial rentan seperti kaum perempuan, etnis minoritas, disabilitas, atau kaum lesbian dan homoseksual. ${ }^{37}$

Di dalam struktur, seseorang tidak dapat menentukan pilihan atas dasar keinginannya pribadi karena hal tersebut ditentukan oleh serangkaian aturan dan ketetapan lembaga-lembaga yang berkuasa. Kerentanan semacam ini sangat mungkin dialami atau menerpa masyarakat yang dikategorikan sebagai tidak berdaya, miskin, terpinggirkan, tidak beruntung, dan lain sebagainya. Young menyebut situasi dan kondisi ketidakadilan semacam ini sebagai kesalahan moral karena ada sekelompok orang yang diuntungkan dan sekelompok yang lain dirugikan melalui kebijakankebijakan yang tidak memihak. ${ }^{38}$ Penilaian Young ini senada dengan Catherine Lu yang mengkategorikan bentuk ketidakadilan semacam itu sebagai kesalahan moral yang berbeda dari tindakan represif yang dilakukan secara individual atau kebijakan represif suatu negara. ${ }^{39}$ Penulis juga sepakat berdasarkan penilaian bahwa ketidakadilan dalam bentuknya yang paling dasar sekalipun adalah sebuah pelanggaran moral karena mengabaikan hak-hak dasar orang lain untuk mengembangkan diri, untuk memenuhi kebutuhan-kebutuhan hidup, dan untuk menentukan nasib hidupnya sendiri. 
Politik Persamaan - Young menolak pengandaian tentang perbedaan sebagai sesuatu yang harus dicegah dan ditolak, melainkan sebagai kenyataan yang harus diakui dan diterima. Politik persamaan menegaskan tentang perlunya mengesampingkan perbedaan demi prinsip persamaan dan kesatuan sosial. Sebagaimana dikatakan Young, "Prinsip perlakuan yang sama awalnya muncul sebagai jaminan formal atas perlakuan inklusif yang adil. Namun, interpretasi mekanis atas keadilan pada akhirnya juga menekan dan menyangkal perbedaan. ${ }^{40}$ Dan lanjut Young, "Politik perbedaan menyiratkan untuk mengesampingkan prinsip perlakuan yang sama dengan prinsip bahwa perbedaan kelompok harus diakui dalam kebijakan publik dan dalam kebijakan maupun prosedur lembaga ekonomi, untuk mengurangi penindasan aktual atau potensial." ${ }^{41}$ Dari pernyataan di atas terlihat dengan jelas keyakinan Young mempersoalkan politik persamaan yang dianggapnya menjadi hambatan serius terwujudnya keadilan.

Dari penyataan Young di atas kita dapat memahami bahwa politik persamaan mengandung dilematis di mana prinsip perlakuan yang sama sebagai jaminan formal atas perlakuan inklusif yang adil justru menciptakan ketidakadilan karena implikasinya terhadap perbedaan yang melandasi eksistensi sebuah masyarakat. Bagaimanapun, interpretasi lebih jauh terhadap keadilan berhadapan secara dengan kenyataan bahwa kelompok-kelompok yang berbeda dan beragam harus diakui dan diakomodasi dalam berbagai kebijakan publik dan prosedur sosial, ekonomi, dan politik untuk mengeliminasi penindasan, baik yang aktual maupun potensial. Pandangan semacam ini tidak dapat dielakkan dalam konsepsi politik kontemporer mengingat bahwa kadang-kadang mengakui hak-hak dan kekhususan-kekhususan tertentu dari kelompok-kelompok yang berbeda merupakan cara untuk mempromosikan partisipasi dalam politik demokrasi.

Adam James Tebble menilai pemahaman Young sangat penting untuk semakin memahami eksistensi dan kehadiran dari jenis-jenis kelompok sosial yang berbeda yang didasarkan atas ras, agama, etnisitas, usia, dan seksualitas dimana dapat terjadi bahwa perbedaan-perbedaan tersebut saling bersinggungan satu dengan yang lainnya dan menghasilkan identitas kelompok terdiferensiasi yang majemuk. ${ }^{42}$ Ackelsberg 
memiliki penilaian serupa bahwa konfrontasi antara politik keadilan dan perbedaan diperlukan karena ada jenis-jenis perbedaan yang tidak dapat diasimilasikan atau dimasuki. Salah satunya adalah kehidupan masyarakat perkotaan yang paradigmatis dan problematis. ${ }^{43}$

Dengan alasan yang sama Günter H. Lenz \& Antje Dallmann menilai bahwa politik perbedaan yang digagas Young merupakan sebuah visi publik heterogen sebagai sebuah ideal masyarakat yang menekankan keterbukaan terhadap perbedaan dan keberlainan yang tidak terasimilasi ke dalam sebuah komunitas homogen. ${ }^{44}$ Karena itu, upaya Young untuk memfokuskan kembali perhatian, baik akademis maupun populer, pada perbedaan kelompok yang dihasilkan dari kekuasaan struktural, termasuk dalam konteks pembagian kerja, dan lain-lain, harus terus-menerus direfleksikan dan diwacanakan.

\section{Wacana Inklusi Demokrasi}

Sebelum menjawab persoalan terkait syarat inklusi Young, pertama-tama akan diuraikan hakikat inklusi demokrasi menurut Young, yang mengarah kepada pemahaman baru terkait inklusi. Sesuai dengan kajian dan analisis terhadap pemikiran dan gagasan Young tersebut, dapat dikemukakan dan dideskripsikan setidak-tidaknya tiga aspek penting terkait dengan substansi atau hakikat inklusi, yaitu partisiasi dan legitmasi, prinsip non-dominasi, dan pemberdayaan. Ketiga aspek ini akan diuraikan satu per satu di bawah ini.

Pertama terkait dengan Partisipasi dan Legitimasi Demokrasi. Refleklsi Young terhadap situasi politik di atas mengarahkannya menggagas inklusi demokrasi dengan premis dasar, "keputusan demokratis secara normatif sah atau obyektif hanya jika semua yang terpengaruhi atau terdampak oleh keputusan terlibat dalam proses diskusi dan pengambilan keputusan." ${ }^{45}$ Gagasan ini memperlihatkan dua norma penting yang mengabsahkan demokrasi, yaitu partisipasi dan legitimasi demokrasi. Secara ontologis, keterlibatan dalam demokrasi menyiratkan bahwa semua orang berada dalam satu waktu di satu tempat untuk bersama-sama mendiskusikan problem kolektif mereka. Di dalam prosedur pengambilan keputusan, dimana keterlibatan 
menjadi kriteria dan ukuran penting, otonomi menjadi pertimbangan sehingga masyarakat dapat menentukan nasib sendiri (self-determination) dan mengembangkan diri mereka sendiri (self-development).

Menurut Young, politik inklusi berperan penting dalam sebuah tatanan demokrasi terutama ketika negara dan pemerintahan memiliki sejarah mengecualikan atau mengabaikan beberapa kelompok, dan berupaya mengasimilasi mereka ke dalam satu budaya dominan. ${ }^{46}$ Alasan kedua dan lebih umum adalah untuk mewujudkan nilai demokrasi, yaitu mempromosikan keadilan. ${ }^{47}$ Bagaimanapun, hanya warga negara, baik individu maupun kolektif, yang sungguh-sungguh memahami apa yang menjadi kepentingan dan kebutuhan mereka. Setiap warga negara harus memiliki hak dan kesempatan yang efektif untuk mengejar kepentingannya yang sah melalui proses politik. Dengan demikian, menurut Young mengakui semua anggota masyarakat dalam kekhususan mereka dan memberi mereka kesempatan untuk mengejar kepentingan mereka yang sah adalah alasan yang baik menganjurkan perhatian khusus pada inklusi bagi unit-unit sosial yang kurang beruntung atau terpinggirkan. ${ }^{48}$

Bayangkan apa yang dikemukakan Michael Walzer ini, "Sekelompok birokrat berunding dengan sangat serius selama berjam-jam dan kemudian melakukan apa yang mereka simpulkan adalah hal yang benar untuk dilakukan - tanpa memperhitungkan preferensi mayoritas rakyat yang tercatat atau kepentingan koalisi kelompok apa pun yang saat ini membentuk mayoritas." ${ }^{49}$ Ini adalah kekeliruan teoretis, dan kekeliruan ini perlu direformasi dengan menganjurkan sebuah keterlibatan bagi semua orang yang terdampak keputusan tersebut. Kerisauan Walzer beralasan karena baginya itu bukanlah sebuah cara yang tepat sebuah pemerintahan demokratis.

Mendukung Young, Martinez-Bascunan mengemukakan bahwa inklusi mengandung dua maka, yaitu partisipasi dan transformasi. Sebagai partisipasi yang tujuan utamannya adalah memberikan kesempatan yang sama kepada semua partisipan untuk mengembangkan kapasitas dalam mengekspresikan pengalaman dan membentuk fakultas imaginasi dan kognisi. Sementara transformasi mengacu kepada 
kemungkinan mentransformasi debat publik, karena ia bertujuan menyertakan suara pihak lain yang ditempatkan dalam posisi rendah atau marginal. ${ }^{50}$

Karena alasan itulah, John Anderson dan Birte Siim menilai bahwa visi inklusi Young memiliki konsep dasar yang unik dan berbeda terutama karena penekanan pada pentingnya pemahaman terhadap ketidaksetaraan sosial dan perlunya melibatkan berbagai perspektif sosial yang berbeda dalam politik. ${ }^{51}$ Ini memperlihatkan bahwa melalui pendekatan inklusi terjadi pengakuan timbal balik antara para partisipan dalam upaya bersama merumuskan dan menemukan solusi terkait masalah kolektif mereka. Pengakuan sangat penting karena hal tersebut mengandaikan ada pemahaman diantara peserta terhadap 'yang lain”. Jika tanpa pemahaman diantara para partisipan, maka sebuah deliberasi sebetulnya sudah menemukkan jalan buntu sejak awal.

Kedua adalah Prinsip Non-Dominasi sebagai nilai penting iknlusi. Di atas sudah dijelaskan bagaimana dominasi dan penindasan menjadi salah satu penyakit kronis demokrasi. Yang berkuasa memiliki kewenangan untuk mengatur dan merumuskan kebijakan-kebijakan yang diperlukan bagi masyarakat, sementara yang tidak berkuasa wajib mengikuti dan menaatinya. Inklusi dalam pandangan Young dapat membantu mengatasi dominasi dan mempromosikan kebijakan yang lebih adil. Meski diketahui bahwa tidak ada yang abadi dalam politik, tapi usaha keras menuntut kesetaraan dan keadilan dalam demokrasi seringkali membuahkan hasil. Salah satunya melalui promosi dan sosialisasi persuasif dan kontinu tentang pentingnya memandang dan menghargai setiap suara individu sebagai sesuatu yang bernilai sehingga layak diperjuangkan.

Prinsip non-dominasi berarti kesempatan dan kebebasan bagi warga negara untuk menentukan diri sendiri (determinasi diri) dan ini bersesuaian dengan gagasan tentang "bersama-sama dalam perbedaan". ${ }^{52}$ Prinsip non-dominasi menyiratkan hubungan antar individu yang memungkinkan terciptanya sebuah kolektivitas dan solidaritas. Mereka yang mengalami dominasi kerap mengeluhkan ketidakadilan dan dengan demikian menuntut perlakuan yang sama dan setara, sehingga prinsip ini diharapkan dapat mempromosikan keadilan. Untuk mencapai keadilan, sebuah 
masyarakat harus dibebaskan dari dominasi. Jika demikian halnya, menjadi penting prinsip non-dominasi diterapkan dalam praktek politik karena prinsip tersebut merupakan nilai politik yang utama. Ini dapat diwujudkan melalui relasi antar individu maupun kelompok dalam deliberasi. Interaksi yang didasari prinsip nondominasi mengisyaratkan hubungan tanpa paksaan dan penindasan. Prinsip nondominasi mengandaikan bahwa setiap individu menjadi subyek dari kepentingan dan keinginannya sendiri. Setiap individu adalah makluk bebas yang memiliki hak dan kehendak untuk menyatakan keinginan dan mengutarakan pendapatnya pribadi.

Gagasan non-dominasi sejalan dengan prinsip kebebasan Philip Pettit, yaitu pertama, bebas bertindak dan menentukan diri berdasarkan kesempatan yang tersedia. bebas mengekspresikan kemampuan untuk mengidentifikasi sesuatu yang pantas dilakukan, dan bebas mengekspresikan status sosial yang memungkinkan mereka menentukan diri mereka sendiri sesuai dengan ciri-ciri dan identitas yang melekat pada diri mereka. ${ }^{53}$ Prinsip non-dominasi menyiratkan bahwa kelompok yang berkuasa tidak berada dalam posisi mengintervensi atau mempengaruhi yang lainnya (non-interference), sebaliknya memungkinkan setiap individu atau kelompok untuk menentukan diri sendiri dan mengembangkan diri sesuai dengan keinginan dan kemampuan yang dimiliki.

Prinsip inklusi berikutnya adalah Pemberdayaan Sosial Kolektif. Young menuntut pemberdayaan dalam pengertian memberi ruang dan kesempatan bagi warga untuk menentukan nasib mereka sendiri (self determination) dan mengembangkan diri (self-development) ${ }^{54}$ Young menilai bahwa pemberdayaan merupakan gagasan yang tepat dan rasional untuk mengatasi eksklusi karena bertitik tolak dari perspektif komunitarian yang bersifat publik, melampaui otonomi yang lebih bersifat pribadiah atau individualistik. ${ }^{55}$ Melalui pemberdayaan, Young meyakini keadilan bagi semua orang akan terwujud. ${ }^{56}$ Ide dasarnya bahwa agar demokrasi benar-benar bermakna bagi semua masyarakat, terutama bagi mereka yang dikucilkan atau yang tidak beruntung, maka ia harus mulai dengan memberdayakan masyarakat biasa. 
Pemberdayaan yang dimaksudkan lebih bersifat kolektif yang bertujuan mendorong partisipasi demokratis, refleksi diri yang kritis, dan tindakan-tindakan kolektif. ${ }^{57}$ Dengan demikian, pemberdayaan didefinisikan atau dimaknai sebagai proses dimana individu, orang-orang yang secara relatif tidak memiliki kekuasaan terlibat dalam dialog dengan yang lainnya dan dengan demikian terbuka untuk memahami sumber daya sosial dari ketidakberdayaan mereka dan melihat kemungkinan untuk bersamasama bertindak mengubah lingkungan sosial mereka. ${ }^{58}$ Dari definisi ini kita dapat melihat pentingnya usaha bersama untuk mencapai tujuan. Tindakan kolektif hanya akan efektif bila individu-individu bergerak bersama mengatasi problem kolektif mereka dan mengusahakan kebebasan dan kesetaraan. Untuk mencapai hal tersebut dibutuhkan sebuah kesadaran kolektif. Kemampuan semacam itu diperlukan agar orang-orang tidak terjebak dalam gagasan naturalistik yang membatasi potensi individu untuk berkembang dan mewujudkan diri. Sebagaimana yang terjadi dalam kehidupan banyak kaum perempuan atau orang-orang yang tidak berdaya yang menerima keputusan dan kebijakan otoritas tanpa kritis.

Konsepsi pemberdayaan juga dikemukakan Majorie Mayo untuk menggambarkan peningkatan kapasitas masyarakat yang mampu mengatur diri sendiri dan menolong diri sendiri dalam menghadapi peningkatan kebutuhan sosial tetapi yang mengalami penurunan dalam hal kesejahteraan publik. ${ }^{59}$ Sejalan dengan itu, untuk mencapai pemberdayaan yang efektif, McClenaghan mengusulkan perlunya membangun kemitraan strategis antara seluruh komponen masyarakat, badan pemerintah, otoritas hukum dan para wakil dan anggota organisasi lainnya. ${ }^{60}$

Pada akhirnya pemberdayaan diperlukan untuk penguatan kapasitas peserta dan menjamin proses dan keputusan demokrasi yang lebih adil. Penguatan dilakukan melalui koordinasi dan kerja sama yang efektif di antara unit-unit sosial dan kultur yang tersebar dan bahkan menjelma dalam banyak institusi atau organisasi yang mewakili kepentingan masyarakat yang terkucilkan. Dengan cara ini, fokus pengambilan keputusan dan pembuatan kebijakan dapat bergeser dari klaim kepentingan pribadi atau kelompok yang saling bersaing, yang seringkali merugikan kaum marginal, menjadi dialog yang lebih berbasis data dan fakta. 


\section{Wacana Komunikasi Inklusif}

Untuk mewujudkan partisipasi dan mencapai keadilan yang diinginkan di mana ada pengakuan terhadap partikularitas dan perbedaan, Young mengusulkan sebuah model komunikasi yang lebih inklusif, atau yang disebutnya demokrasi komunikatif. ${ }^{61}$ Komunikasi demokratis menurut Young adalah upaya rasional melalui kebiasaan sehari-hari untuk mencapai kesepahaman dan saling pengertian yang dapat mengarah kepada keadilan. Model komunikasi yang dimaksudkan adalah sapaan (greetings), retorika (rhetoric), dan narasi (narrative / storytelling).

Apa yang dimaksudkan Young dengan sapaan (greetings) adalah gerak-isyarat (gesture) yang umumnya dilakukan oleh orang-orang ketika bertemu dalam sebuah pertemuan publik, yang dalam konteks politik mengandung pesan tertentu yang sering terabaikan. ${ }^{62}$ Sapaan dalam bentuk gerak-isyarat atau yang umumnya disebut bahasa tubuh (body language), seperti mengucapkan "hai" atau "apa kabar?", tersenyum, berjabat tangan, cipika-cipiki, atau memberikan pelukan sering tidak menjadi pertimbangan penting dan bahkan dianggap sebagai sebuah bentuk komunikasi biasa.

Sapaan sesungguhnya mengandung pengakuan subyek kepada subyek dan dengan sendirinya upaya saling mengekspresikan informasi atau pengalaman diantara mereka. ${ }^{63}$ Hubungan antar pribadi adalah sesuatu yang pertama-tama mesti dibangun dan hal tersebut dilakukan pertama-tama melalui tegur sapa diantara masing-masing pribadi. Dengan cara itu, akan terbentuk kedekatan dan simpati. Model sapaan dengan sendirinya mendorong orang-orang untuk keluar dari dirinya dan berjumpa dengan yang lain dalam keberadaan mereka yang hakiki. Ketika seseorang menyapa yang lain, bahkan yang asing sekalipun, hal tersebut mengirim pesan pengakuan akan keberadaan mereka. Menyapa tidak saja berarti mengakui keberadaan yang lain, tetapi juga membuka diri untuk menerima yang lainnya. Meminjam Levinas, itu berarti seseorang yang menyapa tersandera dan terarah pada kehadiran yang lain. Yang lain merupakan subyek yang menggugah perhatian dan mengundang individu lain untuk membangun komunikasi dengannya. Tindakan komunikasi semacam ini 
oleh Young disebut sebagai momen etis. Dikatakannya, komunikasi tidak akan pernah terjadi jika seseorang tidak pernah bergerak keluar dari dirinya, bertanggung jawab terhadap yang lain dan menyatakan dirinya tanpa iming-iming jawaban atau penerimaan. ${ }^{64}$ Ini menunjukkan bahwa relasi komunikasi terjadi hanya ketika individu memiliki itikad untuk keluar dari subyektifitasnya, bahkan pada tingkat tertentu menyangkal subyektifitasnya untuk menyambut dan menerima yang lain.

Tentu saja sapaan tidak selalu mengandung pesan positif. Dalam pertemuan politik antara kelompok-kelompok yang berseteru, sapaan dapat mengandung pesan perlawanan atau permusuhan. Gerak-isyarat yang ditunjukkan pada saat saling menyapa akan memberikan gambaran yang lugas kepada para pihak atau publik tentang sikap dan pendirian masing-masing. Gerak-isyarat ini akan mempengaruhi proses dan hasil diskusi dan deliberasi. Bagaimanapun, sikap yang berbeda yang ditunjukkan oleh para pihak ketika saling menyapa menjadi kunci berhasil atau tidaknya pertemuan yang diadakan. Inilah yang terjadi dalam pertemuan antara Presiden Tiongkok Xi Jinping dan Perdana Menteri Jepang di sela-sela pertemuan ke-22 Kerja Sama Ekonomi Asia-Pasifik (APEC) pada 2014 silam dimana gerakisyarat berjabat tangan antara kedua pemimpin tersebut dijuluki sebagai "jabat tangan paling canggung di dunia". ${ }^{65}$ Pada saat itu, keduanya melakukan jabat tangan tanpa ekspresi sebagai bentuk pernyataan ketidaksukaan. Ini terjadi menyusul serangkaian perselisihan antara kedua negara terkait sejarah dan sengketa pulau Diaoyu atau Senkaku.

Meski atmosfirnya tidak selalu positif, sapaan tetap diyakini menjadi peluang untuk membangun relasi yang baik diantara peserta diskusi. Young sendiri mengakui bahwa gerak isyarat menyapa akan membantu menciptakan relasi yang setara dan respek timbal balik di antara pihak-pihak yang terlibat diskusi atau deliberasi, dengan demikian terbangun kepercayaan dan koneksi diantara mereka. ${ }^{66}$ Young menyadari bahwa pihak-pihak yang terlibat hanya mungkin memasuki ruang diskusi atau deliberasi dengan terlebih dahulu saling menyapa diantara mereka. Meski terkesan sedikit ritualistik, menyapa setidak-tidaknya membawa masing-masing pihak ke 
dalam suasana dan situasi kebatinan yang lebih positif. Bahkan Young menganjurkan untuk melakukannya dalam suasana dan situasi interaksi yang jauh dari kesan politis. Dalam analisis semiotik, Enfield menyebutkan bahwa tuturan dan gerak isyarat yang digunakan setidak-tidaknya terkait erat dengan tiga faktor, diantaranya (1) ruang dan waktu di mana keduanya dihasilkan, 2) ekspresi yang eksplisit diperlihatkan pada saat keduanya diproduksi, 3) tatapan mata untuk mengarahkan perhatian pendengar atau lawan bicara ${ }^{67}$ Ketiga hal di atas, ruang-waktu, ekspresi, dan tatapan mata memiliki peran penting dalam politik karena sangat menentukan tingkat keberhasilan sebuah diskusi atau deliberasi. Dalam setiap sapaan, tanpa disadari selalu terkandung makna yang terhubung dengan situasi sosial kehidupan manusia. Dalam banyak masyarakat tanda atau isyarat dianggap sebagai elemen publik dari proses kognitif dan menjadi bukti kuat terkait niat komunikasi yang disampaikan orang lain. ${ }^{68}$ Penggunaan kata-kata sapaan dan gerak-isyarat hanyalah sebagian dari sumber daya yang diperlukan untuk mengenali niat komunikasi dan informasi orang lain. Dalam hal ini, diperlukan intuisi yang mana menurut Young merupakan faktor penting dalam komunikasi.

Ringkasnya, makna etis dalam tindakan menyapa adalah menyapalah tanpa berharap orang atau pihak lain melakukan hal yang sama. Transformasi sikap atau cara pandang pihak lain terjadi sebagai konsekuensi dari tindakan menyapa tersebut. Menyapa, karenanya, adalah tujan pada dirinya sendiri. Prinsip etis menyapa dapat dirumuskan menjadi sebuah aksioma, "menyapalah orang lain sedemikian karena memang demikianlah seharusnya anda lakukan". Inilah yang disebut "menyapa tanpa pamrih". Dapat dibayangkan ketika tindakan komunikasi semacam ini dilakukan oleh semua individu, maka subyektifitasnya akan meluruh dan tercipta ruang interaksi yang saling menyilang antar individu. Inilah model komunikasi yang disebut Young demokrasi komunikatif. Setidak-tidaknya dengan saling bertegursapa, setiap orang akan merasa diterima atau diakui kehadirannya oleh yang lainnya. Tindakan semacam ini akan memberi kesempatan dan peluang bagi terciptanya konsensus yang acceptable (dapat diterima), meski barangkali tidak dapat memenuhi keinginan dan harapan semuanya. 
Model komunikasi demokratis kedua adalah retorika. Menurut Young retorika adalah cara menyampaikan sesuatu secara meyakinkan sehingga dapat mempengaruhi emosi, menyentuh hati, dan menggugah imajinasi. ${ }^{69}$ Definisi Young di atas mencakup dua hal, yaitu cara atau pendekatan dan tujuan reteorika. Terutama, bagaimana retorika seharusnya dipraktekkan dan apakah cara tersebut dapat mempengaruhi pendengar atau orang lain. Ia meyakini retorika merupakan cara komunikasi politik yang dapat membentuk keterhubungan dan menciptakan keterlibatan dengan yang lainnya. ${ }^{70}$ Konsep retorika mengasumsikan perbedaan antara 'apa' (what) yang dikatakan sebuah wacana, apa konten, atau pesan substantifnya, dan 'bagaimana' (how) mengatakannya. ${ }^{71}$ Secara umum, ada beragam cara untuk menyampaikan pesan atau substansi yang dikemas dengan gaya dan teknik retorika tertentu.

Definisi Young di atas serupa dengan definisi Martin, yang melihat retorika sebagai kemampuan atau teknik wacana persuasif yang dipakai atau digunakan oleh seorang orator (rhetor). ${ }^{72}$ Demikian halnya juga definisi dari Kuypers dan King yang menilai retorika sebagai penggunaan strategi komunikasi, baik lisan atau tertulis, untuk mencapai tujuan yang diharapkan. ${ }^{73}$ Yang pertama, melibatkan strategi, atau sifatnya disengaja, dengan menggunakan pilihan kata-kata atau bahasa yang tepat, dan yang kedua melibatkan pengetahuan tentang tujuan yang ingin dicapai melalui bahasa yang digunakan.

Dalam pandangan Young, teknik meyakinkan pihak lain adalah tujuan yang harus dicapai dari sebuah retorika. Ini terlihat dari penekanannya pada aspek ilokusi dan perlokusi dari sebuah retorika, dan bukan pada lokusinya. Aspek perlokusi inilah yang kemudian diasosiasikan dengan retorika, ${ }^{74}$ yaitu bagaimana menggunakan retorika secara persuasif untuk menimbulkan efek impulsif bagi para pendengar atau pihak lain. Karena terkait dengan inklusi dalam demokrasi, retorika adalah upaya meyakinkan pihak lain untuk bersama-sama membongkar eksklusi dan mengembangkan inklusi. Menggunakan retorika berarti menggunakan keterampilan atau kemampuan persuasi, yaitu instruksi dalam teknik komunikasi untuk mencapai persuasi. Atau dalam terminologi yang lain retorika bertujuan mencapai sebuah etos, 
yaitu interpretasi pendengar terhadap kualitas yang dimiliki oleh seorang pembicara saat menyampaikan pesannya. ${ }^{75}$

Retorika yang baik menurut Young setidak-tidaknya memenuhi kriteria tertentu diantaranya pertama, atmosfir emosi pada saat berceramah atau berpidato menyampaikan pendapat atau usulan. Apakah ada ketakutan, harapan, kemarahan, kegembiraan, dan ekspresi bergairah lainnya yang muncul di seluruh aktivitas ceramah atau pidato tersebut. Kedua, penggunaan bahasa figuratif seperti metafor, kiasan, permainan kata, juga gerak tubuh figuratif seperti tersenyum, menunjuk, mengepalkan tangan, menggeleng atau menganggukan kepala, dan sebagainya. Atau ungkapan figuratif lainnya seperti puisi, lagu, teater, dan lain sebagainya. Ketiga, Penggunaan media visual dan simbol yang menggugah hasrat atau menginspirasikan pendengar. Dan keempat, kemampuan memperhatikan dan mengenali kekhususan yang menjadi ciri khas atau karakter para pendengar dan memahami berbagai asumsi, sejarah, dan berbagai idiom khusus yang menjadi ciri khas mereka. ${ }^{76}$

Young melihat retorika memiliki peran yang sangat positif dalam politik setidaktidaknya karena beberapa alasan, pertama, retorika dapat membantu memasukkan masalah dalam agenda deliberasi. ${ }^{77}$ Penggunaan retorika di banyak kesempatan berhasil mengarahkan peserta membahas isu-isu krusial dan penting dan pendapatpendapat yang dikemukakan oleh para pihak ditanggapi dengan serius. Kedua, retorika dapat menunjukkan tuntutan dan argumen yang cocok dengan sebuah publik khusus dalam situasi khusus. ${ }^{78}$ Retorika bermanfaat membantu pembicara menyampaikan tuntutan dan argumentasi yang dapat menjangkau kepentingan semua pihak. Kalaupun hal tersebut terkait dengan kepentingan tertentu, setidak-tidaknya dengan argumentasi yang tepat dan rasional kepentingan tersebut dapat diterima atau dipahami oleh pihak lain. Terakhir retorika mendorong para pihak untuk bergerak dari penalaran ke penilaian. ${ }^{79}$ Tidak semua tuntutan dan argumen politik bersesuaian dan dapat diterima oleh pihak-pihak yang terlibat dalam deliberasi. Tetapi biasanya terdapat beberapa argumen yang mungkin bersesuaian dengan rasionalitas mereka. Ketika hal itu terjadi, retorika diharapkan dapat menyediakan sumber daya yang diperlukan untuk membantu masing-masing pihak mempertimbangkan tuntutan atau argumen bersama dan kolektif. 
Menurut Young, seorang retoris yang baik adalah yang berusaha meyakinkan dan mempengaruhi para pendengar dengan mengarahkan usulan dan argumentasi menuju kepentingan yang bersifat kolektif dan plural, mengajak mereka untuk bersama-sama membuat pertimbangan dan mengubah argumentasi atau cara pandang mereka, sekaligus juga menyemangati mereka untuk menilai, dan tidak menuntut mereka semata-mata untuk tahu. ${ }^{80}$ Karenanya, penggunaan retorika membantu prosesi dari rasionalitas ke aksi yang melibatkan pertimbangan politik semacam itu.

Model komunikasi ketiga adalah narasi atau atau yang disebut juga storytelling. Narasi dibangun berdasarkan peristiwa yang dialami seseorang atau sekelompok orang. Melalui narasi seseorang mengungkapkan atau menyingkapkan pengalaman dirinya atau kelompoknya kepada publik dan mencoba menggugah rasionalitas dan emosi publik sehingga memahami dan menerima pengalaman tersebut sebagai pengalaman bersama. Dalam konteks dan situasi dimana argumen-argumen yang dikemukakan terkesan tidak banyak membantu, narasi atau storytelling diharapkan dapat mempengaruhi dan menggugah emosi dan simpati pihak lain.

Young berpendapat bahwa dalam situasi semacam itu argumen-argumen sendiri tidak banyak dipakai untuk mengutarakan suara publik bagi mereka yang dikecualikan dari wacana tersebut. ${ }^{81}$ Baginya narasi menyediakan fungsi penting dalam komunikasi demokratis, untuk menumbuhkan pemahaman di antara para anggota komunitas yang memiliki pengalaman dan asumsi yang berbeda-beda mengenai apa yang penting. ${ }^{82}$ Sama dengan Hannah Arendt, Young juga menekankan bahwa narasi penting dalam menciptakan makna, karena mereka mengabstrasksikan pengalaman atau pertistiwa. Bagi Arendt narasi adalah strategi mentransformasi pengalaman dan kisah pribadi ke dalam pemaknaan publik. ${ }^{83}$ Atau menurut penuturan Disch bahwa Arendt menggunakan term storytelling untuk menggambarkan pemahaman kritis yang bersumber dari pengalaman. ${ }^{84}$ Demikian halnya Young menekankan pentingnya narasi atau storytelling dalam deliberasi demokratis. 
Kisah-kisah yang sering dinarasikan berdasarkan pengalaman pribadi, seringkali berhasil mengikis dan merobohkan tembok ketidakpedulian dan acuk tak acuh publik, demikian menurut Polletta. ${ }^{85}$ Sebagaimana kita juga saksikan, narasi berhasil membangkitkan simpati dari pihak lain, juga pihak yang berkuasa, dan terkadang mampu memobilisasi aksi melawan kekuasaan dan kesewenang-wenangan sosial. Kadang kisah-kisah yang diproduksi jauh lebih kuat dan berenergi yang mendorong aksi bersama memperjuangkan keadilan dan melawan ketidakadilan dari pada propaganda politik penguasa atau pihak dominan lainnya. Bahkan kadang ceritacerita yang beredar di dalam komunitas sudah dipromosikan sedemikian rupa untuk mendukung gerakan dan aksi publik.

Young mengatakan bahwa seringkali kesaksian seperti itu bersumber dari kisah satu orang yang berdiri atau berbicara mengatasnamakan seluruh anggota kelompok kepada dunia luas, dan menuntut perhatian publik terhadap kelompok mereka. Tidak ada cara yang lebih kuat yang dapat mengisahkan pengalaman penderitaan, penindasan, penganiayaan dan mengundang banyak simpati publik dari pada narasi atau bercerita. Ini telah dibuktikan di banyak tempat dan dalam banyak kesempatan forum politik dimana bercerita berpotensi dan berpeluang mendapatkan lebih banyak dukungan dukungan dari pada dua model komunikasi inklusi lainnya.

Tentu saja Young tidak memaksudkan narasi atau storytelling dalam politik sama dengan kisah atau cerita-cerita pada umum lainnya. Seperti diutarakannya bahwa narasi politik berbeda dari bentuk narasi lain berdasarkan maksud dan konteks audiensnya. ${ }^{86}$ Tujuan narasi politik adalah menarik perhatian pihak lain atau penguasa dengan maksud mendapatkan dukungan serta berusaha mengubah pandangan atau pendirian mereka terkait kebijakan atau peristiwa sosial politik yang dilakukan pihak tertentu yang merugikan dan dianggap tidak adil. Apa yang unik dari penggunaan narasi Young adalah bahwa melaluinya warga negara dapat membangun relasi inklusif yang bertujuan memecahkan dan menyelesaikan problem kolektif atau konflik di antara mereka. 
Dengan bercerita seseorang membangun komunikasi intensif melalui apa yang Arendt sebut "kunjungan imajinatif" ke relung hati dan pikiran para pendengar. ${ }^{87}$ Demikian pun sebaliknya para pendengar dapat mengimajinasikan peristiwa berdasarkan pengalaman tersebut. Seperti dikatakan Jackson, para pendengar mencoba mengakomodasi pandangan yang sangat berbeda, dimana mereka melihat diri sendiri dari tempat yang lain, dari sudut pandang yang berbeda dan menumbuhkan pluralisme di mana perbedaan tidak direduksi menjadi identitas budaya atau pengetahuan, tetapi dilihat dari segi kehidupan. mengalami bahwa, dengan imajinasi, siapa pun di mana pun dapat menemukan cara memahami kemanusiaannya sendiri. ${ }^{88}$ Dengan demikian, narasi tidak saja mengaktifkan peristiwa yang dialami pencerita atau komunitas, tetapi sekaligus mengaktifkan imajinasi para pendengar tentang perstiwa tersebut dan memaknainya seturut pemahaman dan sudut pandang mereka sendiri. Sebagaimana yang juga Bullard sebutkan bahwa narasi adalah sebuah tindakan penyingkapan sejarah masa lalu yang tersembunyi. ${ }^{89}$ Tentu saja, tujuan bercerita adalah mengaktualkan peristiwa dan menghadirkan perspektif lain yang dapat mengimbangi pemikiran otoritas mengenai sebuah peristiwa. Bercerita dengan demikian menghadirkan perspektif yang berbeda dengan maksud memberikan pemahaman yang lebih mendalam dan menyeluruh tentang sebuah peristiwa tertentu.

Dalam narasi itu sendiri terjadi hubungan interaktif antara pencerita yang mengundang partisipasi pendengar dan pendengar yang menanggapinya. Bercerita dengan sendirinya memperkuat struktur sosial dan dialog yang membentuk solidaritas dan toleransi terhadap perbedaan. Interaksi antara pencerita dan pendengar ini sangat penting untuk membawa kesadaran setiap orang ke dalam perasaannya langsung dan serentak menegaskan ikatan sosial diantara mereka yang terungkap dari narasi tersebut.

Secara lebih rinci dapat diuraikan keuntungan narasi dalam politik menurut Young. ${ }^{90}$ Pertama, narasi membantu orang-orang, yang dirugikan karena penderitaan dan penindasan, yang tidak memiliki bahasa atau argumentasi rasional untuk mengartikulasikan, menceritakan pengalaman ketertindasan tersebut dengan cara 
mereka. Kedua, narasi dapat membantu publik atau komunitas sosial tertentu mengungkapkan pengalaman-pengalaman tersituasi dan mengafirmasi afinitas kolektif masing-masing individu. Bercerita akan membantu masing-masing pihak yang bertemu mengenali atau mengidentifikasi latar sosial, kultural, politik, bahkan ideologi dan problem-problem yang identik dan bahkan kolektif yang dihadapi bersama. ${ }^{91}$

Ketiga, narasi dapat membantu menjernihkan stereotip dan meluruskan pra-asumsi. Narasi menjadi media bagi orang-orang atau mereka yang berasal dari komunitas partikular untuk menegaskan tentang pengalaman tersituasi, entah karena kebutuhankebutuhan partikular mereka atau karena batasan-batasan sosial-politik yang mendefinisikan mereka ke dalam kategori tertentu. ${ }^{92}$ Keempat, narasi dapat mengungkapkan sumber nilai, prioritas, atau makna kultural. Salah satu problem sosial nyata yang seringkali terjadi adalah konflik nilai yang bersumber dari pemaknaan dan penghayatan nilai partikular di ranah publik. Terakhir, narasi membantu menentukan pengetahuan yang dapat memperkaya pemikiran. ${ }^{93}$ Kesamaan pengalaman akan memperkuat ikatan sosial diantara mereka, tetapi sebaliknya perbedaan pengalaman akan memperkaya makna dan cara pandang terhadap peristiwa yang menjadi sumber pengalaman tersebut

Narasi dalam perspektif Young menjadi kekuatan karena ketika tindakan tersebut dilakukan, seseorang dapat mengubah sudut pandang orang lain, sehingga dapat menjadi sumber "kekuatan" bersama. ${ }^{94}$ Dengan demikian dapat diartikan bahwa bahwa narasi memiliki kekuatan yang mampu menyelamatkan, memiliki dimensi transformatif yang kuat dan dapat diandalkan. Kekuatan transformatif narasi memungkinkan para pihak yang terlibat dalam proses demokrasi sepakat untuk mendorong aksi bersama melawan dominasi dan menentang ketidakadilan.

\section{Penutup}

Demokrasi adalah salah satu syarat agar sebuah masyarakat dapat terarah kepada keadilan dan kesejahteraan. Dalam konteks ini, sebuah masyarakat dapat disebut adil 
hanya jika syarat-syarat demokrasi, yaitu keterlibatan dan realisasi diri otentik warga negara terpenuhi dan terwujud dengan baik. Sayangnya, meski demokrasi membuka seluas-luasnya keterlibatan masyarakat untuk ikut dalam proses dan pengambilan keputusan, hambatan-hambatan substansial maupun prosedural sering ditemui yang mengakibatkan hasil demokrasi tidak sepenuhnya dapat mewujudkan keinginan dan kebutuhan semua pihak.

Hambatan yang ditemui atau dijumpai dalam praktik demokrasi, terutama yang dialami oleh kelompok-kelompok sosial rentan seperti, kaum perempuan, masyarakat miskin, kelompok disabilitas, kaum lansia, dan lain sebagainya disebabkan karena posisi struktural yang tidak menguntungkan sehingga mereka sering tersisihkan atau terisolasi. Pembenahan tentu saja terutama pada transformasi paradigma struktural yang memungkinkan hadirnya persepsi dan interpretasi yang lebih terbuka dan obyektif kelompok berkuasa atau dominan, isa dilakukan melalui sebuah gerakan politik.

Tindakan politik yang memungkinkan transformasi menurut Iris Marion Young adalah komunikasi sehari-hari berupa bertegur sapa, beretorika, dan berceritera. Ketiga aspek ini sangat menentukan tingkat keberhasilan dalam proses diskusi dan deliberasi publik. Tentu saja ini mengandaikan semua yang terlibat dapat menerima dan memahami perbedaan dan kekhasan masing-masing demi terwujudnya demokrasi yang lebih berkeadilan.

\section{Catatan:}

${ }^{1}$ Robert Dahl, Demokrasi dan Para Pengkritiknya, Terj. Rahman A. Zainudin (Jakarta : Yayasan Obor Indonesia, 1992), 6-8.

${ }^{2}$ Iris Marion Young, on Famale Body Experience (Oxford: Oxford University Press, 2005), 21.

${ }^{3}$ Young, on Famale Body Experience, 21.

${ }^{4}$ Young, on Famale Body Experience, 21.

${ }^{5}$ Young, on Famale Body Experience, 47-55.

${ }^{6}$ Young, on Famale Body Experience, 31.

${ }^{7}$ Young, on Famale Body Experience, 31.

${ }^{8}$ Young, on Famale Body Experience, 35-36.

${ }^{9}$ Young, on Famale Body Experience, 35-36.

${ }^{10}$ Young, on Famale Body Experience, 16.

${ }^{11}$ Young, on Famale Body Experience, 16.

${ }^{12}$ Iris Marion Young, Inclusion and Democracy (Oxford: Oxford University Press, 2000), 17. 
${ }^{13}$ Young, Inclusion and Democracy, 17.

${ }^{14}$ Young, Inclusion and Democracy, 53-57.

${ }^{15}$ Young Inclusion and Democracy, 19.

${ }^{16}$ Young, Inclusion and Democracy, 19.

${ }^{17}$ Judith Bara \& Albert Weale, "Introduction”, Democracy Politics and Party Competition, ed. Judith

Bara \& Albert Weale (New York : Routledge, 2006), 1-20.

${ }^{18}$ Kaare Storm, Democracy as Political Competiton, The American Behavioral Scientist (1986-1994) 35, no. 4/5 (Mar-Jun 1992), 377, https://www.proquest.com/docview/194861482

${ }^{19}$ Young, Inclusion and Democracy, 34.

${ }^{20}$ Young, Inclusion and Democracy, 53.

${ }^{21}$ Young, Inclusion and Democracy, 55.

${ }^{22}$ Iris Marion Young, Justice and The Politics of Difference (Princeton, New Jersey: Princeton University Press, 1990), 118-119.

${ }^{23}$ Young, Justice, 38.

${ }^{24}$ Philip Pettit, Republicanism; A Theory of Freedom and Government (Oxford : Oxford University Press. 2002), 22.

${ }^{25}$ Pettit, Republicanism, 22.

${ }^{26}$ Sally Haslanger, Resisting Reality; Social Construction and Social Critique, Oxford : Oxford University Press, 2012), 312.

${ }^{27}$ Haslanger, Resisting Reality, 312.

${ }^{28}$ Saphiro, Politics Against Domination, 20.

${ }^{29}$ Saphiro, Politics Against Domination, 20.

${ }^{30}$ Young, Justice, 49.

${ }^{31}$ Young, Justice, 53.

${ }^{32}$ Young, Justice, 56.

${ }^{33}$ Young, Justice, 59.

${ }^{34}$ Young, Justice, 61.

${ }^{35}$ Iris Marion Young, Responsibility For Justice (Oxford: Oxford University Press, 2011), 45.

${ }^{36}$ Iris Marion Young, "Structural Injustice and The Politics of Difference", in Contemporary Debates on

Political Philosophy, ed. Thomas Christiano \& John Christman (Chichester, West Sussex: Wiley-

Blackwell, 2009), 363.

${ }^{37}$ Young, Structural Injustice, 363.

${ }^{38}$ Young, Responsibility For Justice, 45.

${ }^{39}$ Paige E. Digeser, "Motivation and reconciliation in Catherine Lu's conception of global justice",

Ethics \& Global Politics, 11, 2018, 6-12, https://doi.org/10.1080/16544951.2018.1507385

${ }^{40}$ Young, Justice and the Politics of Difference, 11.

${ }^{41}$ Young, Justice and the Politics of Difference, 11.

${ }^{42}$ Tebble, Adam James. “What Is the Politics of Difference?", Political Theory 30, no. 2, (2002): 259-281, https://www.jstor.org/stable/3072578?seq=1\&cid=pdf-reference\#treferences

${ }^{43}$ Martha Ackelsberg, "Reflections on Iris Marion Young's Justice and the Politics of Difference",

Politics and Gender 4, no. 2, (June 2008), 327, https://www.researchgate.net/publication/248650384.

${ }^{44}$ Günter H. Lenz \& Antje Dallmann, "Justice, Governance, Cosmopolitanism, and the Politics of

Difference. Reconfigurations in a Transnational World Introduction", in Justice, Governance,

Cosmopolitanism, and the Politics of Difference : Reconfigurations in a Transnational World (Berlin:

Faculty of Arts II, Department of English and American Studies, 2007), 9-11.

${ }^{45}$ Young, Inclusion and Democracy, 23.

${ }^{46}$ Iris Marion Young, "Situated Knowledge and Democratic Discussions", in The Politics of Inclusion and Empowerolment - Gender, Class and Citizenship, eds. John Andersen dan Birte Siim (Basingstoke : Palgrave Macmillan, 2004), 19.

${ }^{47}$ Young, "Situated Knowledge", 20

${ }^{48}$ Young, "Situated Knowledge", 20

${ }^{49}$ Michael Walzer, Poitics and Passion, (New Heaven \& London : Yale University Press, 2004), 107

${ }^{50}$ Walzer, Poitics and Passion.

${ }^{51}$ Walzer, Poitics and Passion, 4.

${ }^{52}$ Young, on Famale Body Experience, 139-159.

${ }^{53}$ Pettit, Republicanism, 4.

${ }^{54}$ Young, Inclusion and Democracy, 31-33.

${ }^{55}$ Young, Justice, 251. 
${ }^{56}$ Young, Justice, 248-256.

57 Iris Marion Young, Intersecting Voices: Dilemmas of Gender, Political Philosophy, and Policy, Princeton: Princeton University Press, 1997), 91.

${ }^{58}$ Young, Intersecting Voices, 91.

59 Marjorie Mayo, (2004), "Exclusion, Inclusion and Empowerment: Community Empowerment? Reflecting on the Lessons of Strategies to Promote Empowerment", in The Politics of Inclusion and Empowermen; Gender, Class and Citizenship, eds. John Andersen and Birte Siim, (Basingstoke : Palgrave Macmillan, 2004), 140.

${ }^{60}$ Pauline McClenaghan, "Redefining Citizenship: Community, Civil Society and Adult Learning" in The Politics of Inclusion and Empowermen; Gender, Class and Citizenship, eds. John Andersen and Birte Siim, Basingstoke: Palgrave Macmillan, 2004), 170-171

${ }^{61}$ McClenaghan, "Redefining Citizenship", 63.

${ }^{62}$ Young, Inclusion and Democracy, 57.

${ }^{63}$ Young, Inclusion and Democracy, 57.

${ }^{64}$ Young, Inclusion and Democracy, 57.

${ }^{65}$ https://dunia.rmol.id/read/2014/11/11/179337/Inilah-Jabat-Tangan-Paling-Canggung-di-Dunia.

${ }^{66}$ Young, Inclusion and Democracy, 57, 58.

${ }^{67}$ N. J. Enfield, The Anatomy of Meaning: Speech, Gesture, and Composite Utternces, (Cambridge : Cambridge University Press, 2009), 6.

${ }^{68}$ C. S. Peirce, Philosophical writings of Peirce, (New York: Dover Publications, Peirce 1955), 127-269.

${ }^{69}$ Young, Inclusion and Democracy, 63.

${ }^{70}$ Young, Inclusion and Democracy, 64.

${ }^{71}$ Young, Inclusion and Democracy, 65.

72 James Martins, Politics and Rhetoric: A Critical Introdution (Oxfordshire : Rotledghe Taylor and Francis, 2014), 2.

${ }^{73}$ Jim A. Kuypers \& Andrew King, "What is Rhetoric?", in Rhetorical Criticism: Perspectives in Action, in eds. Jim A. Kuypers, (Lanham : Lexington Books, 2009), p. 4.

${ }^{74}$ Meminjam wacana komunikasi yang dikembangkan Habermas, Young menjelaskan bahwa lokusi adalah maknanya tersurat dari sebuah konten. Ilokusi adalah makna yang diperoleh dari sebuah kekuatan performatif dimana sebuah konten dinyatakan. Perlokusi adalah efek atau dampak yang dihasilkan bagi para pendengar. Ibid, 65-66.

${ }^{75}$ Kuypers and King, "What is Rhetoric?", 47.

${ }^{76}$ Kuypers and King, "What is Rhetoric?", 47.

${ }^{77}$ Young, Inclusion and Democracy, 66.

${ }^{78}$ Young, Inclusion and Democracy, 67

${ }^{79}$ Young, Inclusion and Democracy, 69.

${ }^{80}$ Young, Inclusion and Democracy, 70.

${ }^{81}$ Young, Inclusion and Democracy, 71.

${ }^{82}$ Young, Inclusion and Democracy.

${ }^{83}$ Michael Jackson, The Politics of Storytelling: Violence, Transgression, and Intersubjectiviry, (Copenhagen : Museum Tusculanum Press, 2002), 14-15.

${ }^{84}$ Lisa J. Disch, "More Truth Than Fact; Stroytelling As Critical Understanding in The Writings of Hannah Arendt", Journal Political Theory 21, 4 (November 1993), 665-694. https://journals.sagepub.com/home/ptx.

${ }^{85}$ Franscesca Polletta, It Was Like A Fever: Storytelling In Protest and Politics, (Chicago \& London : The University of Chicago Press, 2006), 3.

${ }^{86}$ Young, Inclusion and Democracy, 72.

${ }^{87}$ Jackson, The Politics of Storytelling, 136.

${ }^{88}$ Jackson, The Politics of Storytelling, 105.

${ }^{89}$ Rebecca Bulard, The Politics of Disclosure 1674-1725 (London : Pickering and Chatto, 2009), 3 - 6.

${ }^{90}$ Young, Inculison and Democracy, $72-77$.

${ }^{91}$ Young, Inculison and Democracy, 73.

${ }^{92}$ Young, Inculison and Democracy, 74.

${ }^{93}$ Young, Inculison and Democracy, 76.

${ }^{94}$ Benhabib, Seyla, Hannah Arendt and the Redemptive Power of Narrative, Journal Social Research 57, 1, (1990), pp. 167-196, http://www.jstor.org/stable/40970582 . 


\section{Sumber Pustaka:}

Ackelsberg, Martha. "Reflections on Iris Marion Young's Justice and the Politics of Difference", Politics and Gender 4, no. 2, (June 2008), https://www.researchgate.net/publication/248650384.

Bara, Judith \& Albert Weale, "Introduction", Democracy Politics and Party Competition, edited by Judith Bara \& Albert Weale. New York: Routledge, 2006.

Benhabib, Seyla. Hannah Arendt and the Redemptive Power of Narrative, Journal Social Research 57, 1, (1990). 167-196. http://www.jstor.org/stable/40970582.

Bulard, Rebecca. The Politics of Disclosure 1674-1725. London : Pickering and Chatto, 2009.

Dahl, Robert. Demokrasi dan Para Pengkritiknya, Terjemahan oleh Rahman A. Zainudin. Jakarta : Yayasan Obor Indonesia, 1992.

Digeser, Paige E. "Motivation and reconciliation in Catherine Lu's conception of global justice", Ethics \& Global Politics, 11, 2018, 6-12, https://doi.org/10.1080/16544951.2018.1507385

Disch, Lisa J. "More Truth Than Fact; Stroytelling As Critical Understanding in The Writings of Hannah Arendt", Journal Political Theory 21, 4 (November 1993), 665-694. https://journals.sagepub.com/home/ptx.

Enfield, N.J. The Anatomy of Meaning: Speech, Gesture, and Composite Utternces. Cambridge : Cambridge University Press, 2009.

Haslanger, Sally. Resisting Reality; Social Construction and Social Critique. Oxford : Oxford University Press, 2012.

https://dunia.rmol.id/read/2014/11/11/179337/Inilah-Jabat-Tangan-Paling-Canggungdi-Dunia.

Jackson, Michael. The Politics of Storytelling: Violence, Transgression, and Intersubjectiviry. Copenhagen : Museum Tusculanum Press, 2002.

Kuypers, Jim A. \& Andrew King. "What is Rhetoric?", in Rhetorical Criticism: Perspectives in Action, edited by Jim A. Kuypers. Lanham : Lexington Books, 2009.

Lenz, Günter H. \& Antje Dallmann. "Justice, Governance, Cosmopolitanism, and the Politics of Difference. Reconfigurations in a Transnational World Introduction", in Justice, Governance, Cosmopolitanism, and the Politics of Difference : Reconfigurations in a Transnational World. Berlin: Faculty of Arts II, Department of English and American Studies, 2007.

Mayo, Marjorie. "Exclusion, Inclusion and Empowerment: Community Empowerment? Reflecting on the Lessons of Strategies to Promote Empowerment", in The Politics of Inclusion and Empowermen; Gender, Class and Citizenship, edited by John Andersen and Birte Siim. Basingstoke : Palgrave Macmillan, 2004.

Martins, James. Politics and Rhetoric: A Critical Introdution. Oxfordshire : Rotledghe Taylor and Francis, 2014.

McClenaghan, Pauline. "Redefining Citizenship: Community, Civil Society and Adult Learning" in The Politics of Inclusion and Empowermen; Gender, Class and Citizenship, edited by John Andersen and Birte Siim, Basingstoke: Palgrave Macmillan, 2004.

Pettit, Philip. Republicanism; A Theory of Freedom and Government. Oxford : Oxford University Press. 2002. 
Peirce, C. S. Philosophical writings of Peirce. New York: Dover Publications, Peirce 1955.

Polletta, Franscesca. It Was Like A Fever: Storytelling In Protest and Politics. Chicago \& London : The University of Chicago Press, 2006.

Storm, Kaare, Democracy as Political Competiton, The American Behavioral Scientist (1986-1994) 35, no. 4/5 (Mar-Jun 1992), 377, https://www.proquest.com/docview/194861482

Walzer, Michael. Poitics and Passion. New Heaven \& London : Yale University Press, 2004.

Young, Iris Marion. Justice and The Politics of Difference. Princeton, New Jersey: Princeton University Press, 1990.

Intersecting Voices: Dilemmas of Gender, Political Philosophy, and Policy, Princeton: Princeton University Press, 1997.

"Situated Knowledge and Democratic Discussions", in The Politics of Inclusion and Empowerolment - Gender, Class and Citizenship, edited by. John Andersen dan Birte Siim. Basingstoke : Palgrave Macmillan, 2004. On Famale Body Experience. Oxford: Oxford University Press, 2005. Inclusion and Democracy. Oxford: Oxford University Press, 2000.

Responsibility For Justice. Oxford: Oxford University Press, 2011. "Structural Injustice and The Politics of Difference", in Contemporary Debates on Political Philosophy, edited by Thomas Christiano \& John Christman. Chichester, West Sussex: Wiley-Blackwell, 2009. 